\title{
Belgeo
}

Revue belge de géographie

3-4 | 2011

Human mobility and housing market during a period of global recession - Miscellaneous

\section{The weak ring of the chain : Immigrants facing the economic crisis in Italy}

Le maillon faible de la chaîne : les immigrés face à la crise économique en Italie

\section{Carlo Brusa and Davide Papotti}

\section{CpenEdition}

\section{Journals}

Electronic version

URL: http://journals.openedition.org/belgeo/7099

DOI: $10.4000 /$ belgeo.7099

ISSN: 2294-9135

Publisher:

National Committee of Geography of Belgium, Société Royale Belge de Géographie

\section{Printed version}

Date of publication: 31 December 2011

Number of pages: 149-166

ISSN: 1377-2368

\section{Electronic reference}

Carlo Brusa and Davide Papotti, «The weak ring of the chain : Immigrants facing the economic crisis in Italy », Belgeo [Online], 3-4 | 2011, Online since 04 December 2012, connection on 19 April 2019. URL : http://journals.openedition.org/belgeo/7099; DOI : 10.4000/belgeo.7099

This text was automatically generated on 19 April 2019

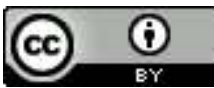

Belgeo est mis à disposition selon les termes de la licence Creative Commons Attribution 4.0 International. 


\title{
The weak ring of the chain : Immigrants facing the economic crisis in Italy ${ }^{1}$
}

Le maillon faible de la chaîne : les immigrés face à la crise économique en Italie

\author{
Carlo Brusa and Davide Papotti
}

\section{Introductory notes}

1 The current global economic crisis, which deeply affected all the countries across the globe, has had a substantial impact on the Italian economic productivity and the social conditions. The job market became more and more selective, increasing the "social competition", especially among the less skilled workers ${ }^{2}$. Immigration as a whole did not diminish job opportunities for the Italians ; on the contrary, it increased them, but only for those sectors that require a higher education and generally for women (Banca d'Italia, 2009). The immigrants, in this scenario of a pervasive and long-lasting crisis, were among the social categories that found themselves, so to speak, on the "front line". The ties between the economic crisis and immigration are various and deep: "The world economic crisis had an important impact on international migration. In particular, the crisis had consequences on the dimensions and the characteristics of migratory flows, the occupational situation of foreign workers in the labour markets of the destination countries, the processes of integration, the level of the remittances towards the countries of origin and the very migration policies" (Bonifazi, Marini, 2011, p. 1) ${ }^{3}$.

2 The communities of foreign citizens living in Italy have been deeply affected by the crisis, with marked differences among the most developed regions (especially concentrated in Northern and Central Italy), and the least developed ones (in Southern Italy). Within every region, though, there are noticeable differences, as far as reactions to the economic crisis are concerned, between metropolitan areas, manufacturing districts, tourist districts, agricultural districts and marginal areas (Allasino, Eve, 2010). 
Our paper aims at offering an introductory interpretative frame to understand some of the consequences that the economic crisis had on the residential choices by immigrants. We do understand that some of the trends we are mentioning in this paper are long-term processes that started before the recent economic global crisis, and will probably persist well after a desirable recovery from it. Nevertheless, it seems quite plausible to state that the recent financial crisis had an accelerating effect in many directions, and can be read, if not as "the" cause of many recent economic and social trends, as one important cause that lies behind several current characteristics of the labour market, the housing market, the mobility flows.

The topic of the current impact of the economic crisis on immigrants worldwide started a vast debate in social sciences (Un-Instraw, 2009; Oecd, 2009a and b; Iom, 2009; Papademetriou, Sumption, Somerville, 2009 ; Hatton, Williamson, 2009; Castles, 2009 ; Castles, Miller, 2009), with the scholars engaged in following a dynamic situation and sketching its potential evolution in the near future (Düvell, 2009). Many disciplines, such as demography, sociology, anthropology, economics, political sciences, geography, psychology provide useful insights to understand the complexity of the numerous and various effects that the economic crisis has on contemporary societies. In this paper, we would like to offer a set of reflections that, revolving around a geographically-oriented reading of the phenomena, focus on two key terms related to the concept of "globility", applied to the Italian context. It would be difficult to provide completely new insights on phenomena that are under the attention of the international community of scholars. In a less ambitious perspective, we aim at providing a commentated overview of the main characteristic of the phenomena in the Italian context, while at the same time suggesting a few key elements that, in our opinion, are crucial in understanding the recent changes in the socio-economic situation of the country. By doing so, we aim at offering to other scholars material for a potential comparison with other countries that are facing similar problems and perspectives.

Mapping in real time the links between a constantly evolving economic situation and the behavior of several fragmented and disseminated communities of foreign citizens living and working on the Italian territory is, of course, a nearly impossible task. What we would like to offer here are some data related to the Italian context that could help further investigations on this subject. Given the difficulty of obtaining precise and updated statistical data about the immigrants' working conditions and about their mobility (at both the Italian national scale and at the international level), the article draws not only from the recent bibliography produced in academic journals, but also on reports made available by both private and public research institutions, and from journalistic sources.

\section{Economic background : the global crisis in Italy and immigration}

6 In order to fully understand the impact of the foreign population on the economic and social performances of the Italian country, a few quantitative data will be useful to provide a general interpretative frame. According to the data released by Istat (Italian National Institute of Statistics) on September, 2011 - data referring to January 1, 2011 the foreign residents in Italy were $4,570,317^{4}$. To this number, according to the estimated figures suggested by the Milan-based "Ismu - Initiatives and Studies on Multiculturalism" 
Foundation, one must add about 443.000 irregular presences ${ }^{5}$. The number of foreign citizens living in the Italian territory thus reaches the number of five millions (that means the $8 \%$ of the total population - approximately 60 millions - living in the peninsula). The geographical distribution among the main administrative partitions shows a higher density of immigrants in the Northern and Central regions (Table 1).

Table 1. Foreign residents in Italy divided by region on January 1st, 2011 (data source : Istat) ${ }^{6}$.

\begin{tabular}{|c|c|c|c|}
\hline Region & $\begin{array}{l}\text { Total } \\
\text { population }\end{array}$ & $\begin{array}{l}\text { Total number of } \\
\text { foreigners }\end{array}$ & $\begin{array}{l}\text { Percentage of foreigners out of the } \\
\text { total population }\end{array}$ \\
\hline Piemonte & $4,457,335$ & 398,910 & $8.94 \%$ \\
\hline Valle d'Aosta & 128.230 & 8,712 & $6.79 \%$ \\
\hline Lombardia & $9,917,714$ & $1,064.447$ & $10.73 \%$ \\
\hline $\begin{array}{l}\text { Trentino-Alto } \\
\text { Adige }\end{array}$ & $1,037,114$ & 90,321 & $8.70 \%$ \\
\hline Veneto & $4,937,854$ & 504,677 & $10.22 \%$ \\
\hline $\begin{array}{l}\text { Friuli-Venezia } \\
\text { Giulia }\end{array}$ & $1,235,808$ & 105,286 & $8.51 \%$ \\
\hline Liguria & $1,616,788$ & 125,320 & $7.75 \%$ \\
\hline Emilia-Romagna & $4,432,418$ & 500,597 & $11.29 \%$ \\
\hline Toscana & $3,749,813$ & 364,152 & $9.71 \%$ \\
\hline Umbria & 906,486 & 99,849 & $11.01 \%$ \\
\hline Marche & $1,565,335$ & 146,368 & $9.35 \%$ \\
\hline Lazio & $5,728,688$ & 542,688 & $9.47 \%$ \\
\hline Abruzzo & $1,342,336$ & 80,987 & $6.03 \%$ \\
\hline Molise & 319,780 & 8,929 & $2.79 \%$ \\
\hline Campania & $5,834,056$ & 164,268 & $2.81 \%$ \\
\hline Puglia & $4,091,259$ & 95,709 & $2.33 \%$ \\
\hline Basilicata & 587,517 & 14,738 & $2.50 \%$ \\
\hline Calabria & $2,011,395$ & 74,602 & $3,70 \%$ \\
\hline Sicilia & $5,051,075$ & 141,904 & $2.80 \%$ \\
\hline Sardegna & $1,675,411$ & 37,853 & $2.25 \%$ \\
\hline
\end{tabular}




\begin{tabular}{|l|l|l|l|}
\hline Italy & $60,626,442$ & $4,570,317$ & $7.54 \%$ \\
\hline
\end{tabular}

7 The recent trends of immigration into Italy show a sharp decrease in the amount of new immigrants entering the country every year. As Giancarlo Blangiardo states in the yearly report by Ismu (2011), the average number of yearly growth of foreign citizens who were residing in Italy was around 390,000 in the period 2003-2009; in 2010, however, the growth dropped to a level of 335,000 . So, if at the beginning of 2003 there were about 1,5 million foreign residents in the country, at the beginning of 2005 they were 2,4 million, of 2007 2,9 million, of 2009 3,9 million. While still relevant, the growth of foreign residents in the Italian territory shows a decrease in the last year, which can be at least partially attributed to the economic crisis.

\section{Immigration and the job market}

8 The current economic crisis had a negative impact on occupational level in the Italian job market (Cnel 2011). The Excelsior Informative System, however, recently shows the first "recovery signals through the occupational needs of the enterprises" (excelsior.unioncamere. net).

9 According to the data produced in October 2010 by the Leone Moressa Foundation, the number of foreign unemployed workers in Italy grew of a percentage of nearly $70 \%$ starting from the early stages of the global economic crisis (September 2008), while the percentage of Italian workers grew at a lower, though still impressive, percentage of the $29.4 \%$ (2010). During the same period, foreign workers' occupation nevertheless grew in raw numbers, with an increase of $10.2 \%$ (reaching the $8.6 \%$ of the total working people, while before the crisis this number was one point below, at $7.6 \%$ ). As the researcher of the Venice-based Foundation summarize : "the economic crisis stroke on everyone, but on immigrants in particular"'. The recent data available in the chapter on the labour market by Laura Zanfrini in the last Ismu report (2011) show a general increase in the number of foreign workers (1.678.374 in the first trimester 2008, 1.945.135 in the first trimester 2009, 2.210.558 in the first trimester 2010, 2.503.458 in the first trimester 2011). From a quantitative point of view, the performance of the foreign immigrants is not particularly negative, especially if compared with the negative trend which characterizes the Italian workforce. From a qualitative point of view, though, the foreign workforce shows evident signs of "stress", which can be at least partially linked to the economic crisis. The foreign workforce tend to be concentrated in non-skilled jobs and in "stagnant" productive sectors that are mostly affected by the global crisis. Together with a persistent gap in the salaries (the foreign workforce tends to be paid less than the Italian equivalent), these aspects confirm the "vulnerability" of the foreign workforce, that still seems to be one of the "weak rings" of the national productive system. The internal composition of the foreign workforce shows, in fact, a small percentage of workers employed in the skilled and technical jobs ( $7.2 \%$ of the total foreign workforce compared to a $37.3 \%$ of the Italian workforce employed in this sector) and in the tertiary employment ( $16.4 \%$ compared to the $29.6 \%$ ). The percentage are of course very different in the lowest classes of the "skill ladder" $: 38.7 \%$ of the foreign workforce is employed as workmen and artisans (compared to a $25.4 \%$ of the Italian one), and 37.7 in jobs that are considered "non-skilled" (compared to a $7.7 \%)^{8}$. 
Figure 1. Foreign population and total population per region.

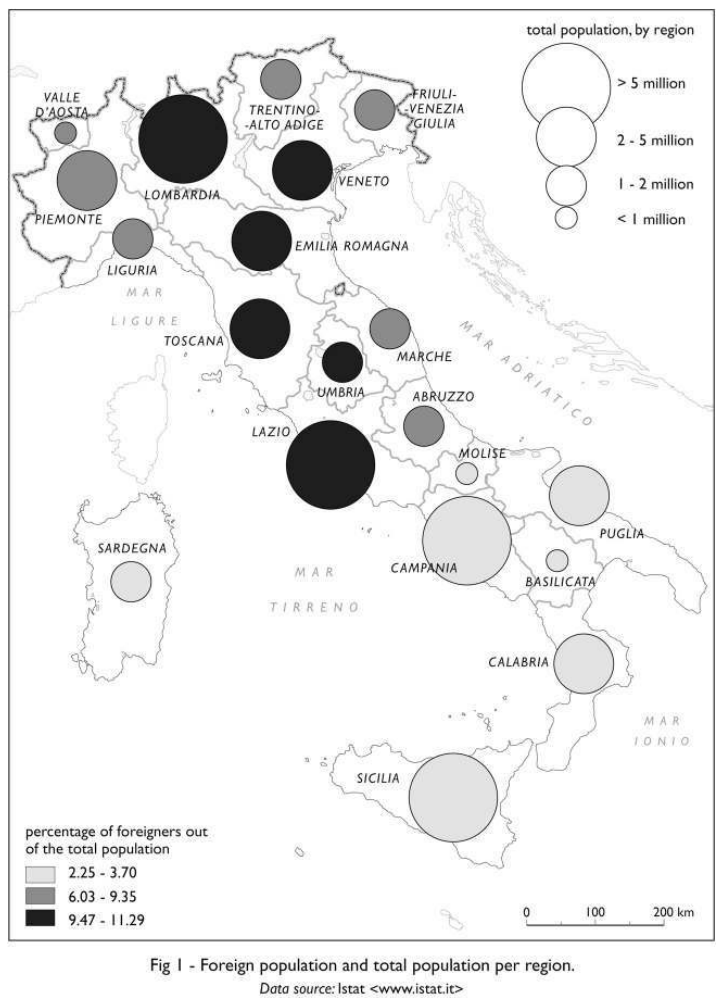

Source : ISTAT (www.istat.it) employment, but it afects a sort ointer one side, and high skilled jobs on the on one side, and high-skilled jobs on the other. If we group the four above mentioned categories used by Zanfrini (skilled and technical jobs, tertiary employment, workmen and artisans, non-skilled jobs) in couples, putting together in one group the first two categories and in a second group the last two ones, we obtain a coherent data in the three macro-regions : $24.5 \%$ of foreign workforce in Northern Italy work in the first group, $23.4 \%$ in central Italy, $21.5 \%$ in the South. That means that $75.5 \%, 76.6$ and 78,5\% work in low skilled jobs. Within this last group, though, we have a marked differentiation about the two different included categories : while in the North the workman are $44.5 \%$ of the total and non-skilled jobs are $31 \%$, in the Center the percentages are respectively 35.5 and 41.2, and in the South 20.5 and 57.9. The "segregation" of workers in the low skilled jobs is thus more relevant in the Southern regions. The highest loss in the number of jobs, on the contrary, is registered mainly in the economically advanced areas, due to the fact that the recession strikes mostly on productive areas. The researches carried on by the Moressa Foundation show that the highest loss in the percentage of foreign workers took place in Northern Italy, where the newly arrived immigrants tend to concentrate, since they can find more employment opportunities (Bonifazi, Rinesi, 2010) ${ }^{9}$.

11 It has to be remembered that the local differences in the presence of foreign citizens show what Maurizio Ambrosini (2005) called the "plurality of territorial models" in the employment of the foreign workforce : every territory has specific characteristics that contribute to create different adaptations to the economic crisis, following a sort of "atlas of resilience". Besides, this varied situation is constantly changing. 
12 According to the XV Report on Migrations 2009 published by the Ismu Foundation, the effects of the recession were clearly detectable since the beginning if one considers the amount of the remittances sent by the immigrants to their own countries. In the first trimester of 2009 , the amount of the total remittances diminished of the $4.7 \%$ from the same period of 2008 (1.48 billion Euros in 2009, 1.55 billion Euros in 2008). The phenomenon seems to be, also at the international level, one of the most recognizable features of the global economic crisis (Ruiz, Vargas Silva, 2009).

The occupational recession affects most of all the living conditions of those who are in a status of "social vulnerability", such as the vast majority of the nearly five millions migrants living in the country, who face a growing uncertainty about the access to work and the length of the hiring contracts. This "vulnerability" can be explained with the increasing difficulty that the post-Fordist productive systems encounter in guaranteeing economically safe living conditions The result is a generalized "loss of the present, together with fear of the future" (Negri, 2006).

\section{The economic crisis and the real estate market}

In the Fifteenth Report on Migrations, Agustoni states that, after a few years during which the housing opportunities for migrants remained unchanged, in 2009 the evolution of the situation, "far from being characterized unilaterally in positive terms, on the contrary showed several problematic aspects" (2009, p. 141). Housing opportunities are a key component in the processes of integration of migrant communities into the hosting society. The "geography" of housing opportunities is another component to be considered in the analysis of the current socio-economic situation in Italy.

The problems of those foreign workers who want to find a house, even if all the other conditions are the same, do change with the cost of the rent, which is very different from town to town. The Sunia (National Unified Union of Renters and Grantees) calculated the average rent in twelve big Italian cities : the amounts oscillate from a monthly average of $€ 630$ in Catania (in Sicilia), $€ 640$ in Bari (Puglia), $€ 700$ in Palermo to a monthly average of $€ 1,430$ in Venice, which is closely followed by Milan $(€ 1,400)$. Two other big cities, that are both international tourist destinations, such as Florence and the country capital, Rome, have an average level of rents of about $€ 1,300$ per month (www.sunia.it).

These few data already suggest the importance of the housing problem for the immigrants. For the vast majority of this category, the possibility to buy a house is only a remote opportunity, even though the data collected by Sunia already showed for the year 2008 a general decrease of $7 \%$ on real estate prices from the previous year. As wellknown, after that year the general economic situation worsened: the number of transactions in the real estate market for the first trimester of the year 2009 decreased by $15.8 \%$ in the province capitals (103 cities and towns across the country), while in the noncapital municipalities decreased of $19.8 \%$. The general stagnation of the housing market in Italy, following the financial crisis of $2008^{10}$, would be a potentially positive factor for immigrants who want to buy a house in Italy; but, since it is caused, and happens together with, a general economic crisis, the real opportunities to access a house remain limited for immigrants (Ismu, 2011). In this perspective, the growing economic and social instability of the immigrants in Italy is also related to a more and more difficult access to proper housing conditions. The explicit link that the Italian legislation on immigrants makes between the permit of stay in the country and a regular job obliges to privilege the 
search for a regular contract, that becomes a pre-requisite for everything else : "The tight link between the permit of stay, the job contract and the access to housing established by the current law, which subordinates the condition of the stay and the social rights to the occupational status, in a phase of acute economic crisis practically obliged immigrants to accept any working condition" (Perocco, Cillo, 2011, p. 13).

\section{Understanding the mobility patterns of immigrants in Italy : the power of attraction at the regional level}

The harsh competition for a permanent job has become a global one, since, as far as work is concerned, "people move" (World Bank, 2009). One of the potential scenarios associated to the global economic crisis is the possibility for migrants to go back to their own country of origin. Was the crisis the sparkle that lighted a new tendency to return : a movement on the same itinerary, but in the different direction? Specifically did the foreign immigrants started to leave Italy? As shown in the international reports (Oecd, 2009a and b; Iom, 2009; Hatton, Williamson, 2009), return migration seems to be an undeniable reality, but not a mass choice. During the year 2009, in Italy there was a noticeable increase $(+19,4 \%)$ in the number of foreign people who withdrew from the municipal demographic records declaring that they were going abroad. The Istat and the Ismu researchers agree in stating that nearly all of these 32,000 foreigners who left Italy were immigrants returning to their own country of origin ${ }^{11}$. The Report on Foreign Population produced by Istat (2010) literally states that "this number is presumably underestimated if compared to the real flows of people leaving the country". The cancellations that have been made from the municipal registers because the foreign citizens could not be contacted, in fact, grew in 2009 of the $33,9 \%$, reaching a number of 56,797 . This data, the Report concludes, probably compensates the above mentioned underestimate. On the other hand, as Pasca (2010) states, it is very unlikely that the economic crisis will bring to a halt to immigration movements towards Italy.

The Italian legislation on immigration closely relates the permit to reside in the country with the possession of a regular job contract. Many immigrants lost their job in the last years, and many of them had to move to other destinations both in Italy and abroad or to re-orient their professional activity. Among the factors that can encourage immigrants to stay in the country even if they lose the job there is the high level of illegal economy that characterizes the Italian productive system, and the fact that the permit of stay is related to job status (if one leaves the country, it is hard to re-enter). As the researchers of the Moressa Foundation put it: "The loss of the job risks to compromise the regular presence on the Italian territory, with subsequent social consequences. Immigrants, since they are obliged to work in order to remain in Italy, are more dynamic in the job search, and in many cases they have to accept low skilled jobs" (our emphasis; see also Albisinni and Pintaldi, 2011). This "dynamicity" can also be interpreted as the availability to move to another place in Italy in order to have a job: the residential choice becomes a consequence of the job opportunities, and this can bring to an increase in the average residential mobility of the immigrants.

19 In this perspective, a research carried on by the Leone Moressa Foundation aimed at estimating, through a series of statistical indicators, the occupational power of attraction that the single regions have on foreign workers acquires a great interest for the 
understanding of the impact of the recession on the national territory ${ }^{12}$. There are ten of these indicators, referring to the years 2008 and 2009. According to the researchers, the first four (the occupational balance, the risk of unemployment, the occupational rate for foreigners and the need for foreign occupation), are useful to measure the effects of the crisis, while the rate of preservation of the permanent job positions and the index of contractual instability are mostly aimed at measuring the quality of the work conditions. The index of turn-over, furthermore, is useful to measure the progressive ageing of the Italian population in its working age. To these indexes one must add two other factors : the average value of the salaries and the average income of foreign workers, as shown in the income-tax returns. The tenth index is the rate of foreign workers entrepreneurship. However, it must be taken into consideration - together with the well-known differences in terms of demographic weight and of economic development that characterize the twenty regional administrative partitions - that the estimate is related only to the foreign immigrants who are regularly employed and possess the permit of sojourn. The study remarks the clear dichotomy, in terms of occupational power attraction - and therefore of residential choices - between the Northern regions and the Southern ones (Perulli, Pichierri, 2010).

20 The situation, however, is more complex than one could think just keeping into consideration the economic potentialities of the different regions (Zanfrini, 2010). A the top of the list there is in fact Friuli-Venezia Giulia (with a score of 134.2, with the national average at 100), where there are the lowest risk of remaining unemployed and the highest rate of foreign entrepreneurship. This last factor, though characterized by a great heterogeneity of situations, still remains a sign of success for the migrant (Ambrosini, 2005, pp. 101-131).

In this ranking, Friuli-Venezia Giulia is followed by Lombardia (with a score of 119.3) : the richest and most populated region of the country, where immigrants can find many and diversified job opportunities. This is the area of the so-called "metropolitan work", which has its epicenter in the city of Milan, with its rich tertiary sector assisting enterprises (Ambrosini, 2005, p. 69). Lombardia also has a very rich industry, which can be found nearly everywhere, especially in the Western high plains and along the territorial axis that goes from Milan to the North-Eastern border (Favaro, Muscarà, 2009). The third region in the ranking of the Moressa Foundation is Trentino-Alto Adige (with a score of 118.7), which is characterized by a high offer of seasonal work, mainly linked to agriculture (especially in the province of Trento) and to tourism. Among the other regions that are characterized by a strong occupational power of attraction there are Liguria (116.8), Lazio (116.3), Emilia-Romagna (112.1) and Toscana (110.9). A the opposite end of the ranking there are the regions of Southern Italy, with scores that are far from the national average. The last region in the ranking is Calabria (with a score as low as 29.2) followed by Puglia (39.2), Molise (55.7), Basilicata (61.4) and Campania (64.9), while a higher power of attraction, though inferior to the national average, characterizes the two insular regions of Sardegna (71.1) and Sicilia (71.3).

In all these regional contexts the value of the single factors is always at the lowest positions in the national ranking. In these areas the recession creates situations of "vulnerability" that are understandably heavier than in the North, where the negative current situation of the economic sector affected socio-economic systems characterized by a higher starting level and by better conditions in the welfare services, which are 
guaranteed by both a better organized public sector and by a more developed and traditionally active private social sector.

\section{Economic changes and the impact on the mobility of immigrants in Italy : some reflections}

It is necessary to take into consideration the links between the flows of immigration (which are strongly influenced by the politics and the jurisdiction about immigration), the different reactions to the economic crisis and the various strategies adopted by immigrants workers to maintain the job and to access the housing system. The economic crisis has been the catalyst of many problems that were already present in the Italian context, but emerged faster at the surface because of the global crisis. These theses were also discussed during a conference, entitled "Immigrati tra Pacchetto sicurezza, crisi economica e integrazione" (Immigrants between Security Package, Economic Crisis and Integration") organized in Imola (BO) by the Council of Foreign Citizens of the Province of Bologna on November 14, 2009. A similar perspective was also offered by the research Gli effetti della crisi economica sugli stranieri immigrati (The Effects of the Economic Crisis on Foreign Immigrants) by the Turin-based Fieri (International and European Forum for Researches on Immigration) and the University of Turin, which was presented in May 2010 (www.fieri.it).

\section{The search for a house as a factor of mobility}

The above mentioned Sunia organization published on July 12, 2009, a report entitled "Immigrants and the house". The research was carried on interviewing a "sample of one thousand families of nationalities other than the European Union ones. The families were residing on the whole national territory and were among the ones which accessed the services provided by Sunia" (www.sunia.it). Reading the report, one learns that the immigrants nearly always face, in renting a house, bigger difficulties than the Italians, starting from a lack of a coherent information system in the migratory project destination place, where often the only sources of information are the ethnic solidarity chains, occasional friends and colleagues at work. The houses for the immigrants are "nearly always expensive or unsatisfying". Sunia denounces the fact that the majority of immigrants is obliged to live "in a status of cohabitation, often of overcrowding, sometimes an extreme one, in houses located in often degraded buildings lacking in services". The general housing sector for immigrants is "informal", made of barracks, sparse warehouses, ruined houses, or rather houses that are no longer suitable for the "ordinary" real estate market, and thus offered to people who must solve the problem of finding a house at prices that are compatible with their - generally low - incomes. Moreover, "the absence of a contract or the registration of an amount for the rent that is inferior to the real one nearly represents the totality of the cases", while "the rents are often increased (of a percentage that goes from $30 \%$ to $50 \%$ ), if compared to the ordinary ones and this factor heavily affects the economic balance of the immigrants, sometimes in an incompatible way" (Agustoni, 2011).

This picture clearly shows relevant difficulties of the immigrants in accessing satisfying housing conditions ; not to mention the obstacle contained in the so-called "House Plan" ( Piano casa) approved with the financial law of 2008 (Law 133/2008, art. 11) and in the so- 
called "Security Package" (Law 94 , 2009, "Regulations in the field of public safety"). The "House Plan" requires that, in order to access the housing welfare services, the immigrants "must have been resident in the national territory for at least ten years, and at least five years in the same Region" (art. 11). The "Security Package", moreover, states that "whoever, in order to gain an unjust profit, hosts or rent a house to a foreigner who is without a permit of sojourn at the moment of the contract signing or contract renewal, is punished with a period from six months to three years of jail" (art. 1, comma 14). Of course all these limitations sum up in increasing the obstacles that foreign citizens face in finding a proper house (Cesareo, 2011).

If the difficulty in accessing a proper housing accommodation has been a characteristic of many immigrant contexts, the Italian one being no exception, the economic crisis has probably been responsible for a growth of the difficulties in the economic and social access to the house. Even without taking into consideration the growing hostility towards immigrants among the Italian population, which can express itself also through increased discrimination in renting to foreign citizens, it is the "vicious circle" sparkled by the economic crisis that can contribute to an increased social and physical mobility, as Perocco and Cillo suggest: "[The tight link between the permit of stay, the job contract and the access to housing established by the current law] at the same time pushed a larger number of immigrant foreign women and youth to enter the labour market, given the status of unemployment or beneficiary of temporary redundancy funds of the husband or the parent: in order both to integrate the family income and to protect the permit of stay and/or the right to family unity. And also incremented the circular mobility of immigrant workers (which takes place especially during the unemployment or the redundancy fund periods), characterize mostly by the return to the cities of first immigration, or towards other European countries, or to the country of origin. At the same time, however, the return in the country of origin, or the move to other countries where the impact of the crisis has been less disastrous, affected only a part of the immigrant population, not surely that component who lives in public housing or bought a house - may be through a mortgage -, who has children at school and started to build roots" (2011, p. 14).

\section{Cities or towns? Mobility within the urban hierarchy}

The foreign population in Italy is still mainly concentrated in cities. The national average of foreign population in the province capitals is $8.7 \%$, and in the big cities $9.4 \%$, compared to the $7 \%$ of the total population. The percentage of foreign population living in province capitals is $36.4 \%$, still higher than the one of the Italian population (28.7\%) (Istat, 2010). Foreign residents, though, started to move to smaller towns and villages, profiting from the dispersed structure of the productive system in Northern and Central Italy and from the lower rents available in small centers. This trend has been documented, for instance, in a key region for immigration, Lombardia ${ }^{13}$. Nearly one fourth (23.2 \%) of the foreigners legally residing in Italy lives in this region, and one tenth just in the province of Milan.

In the Italian context, the internal mobility of foreigners is relatively high. The record linkage system adopted by Conti et al. (2010) in their research (crossed analysis of the archive of the regularization papers in 2004 and of the archive of the renewed permits of stay in 2007) shows that $60 \%$ of the immigrants moved from one place to another. The 
mobility of the foreign component adds up to the traditional mobility, especially between South and North, that, through ups and downs, has been a characteristic of the recent history of the country : "Internal mobility in Italy, after periods of both stagnation and of intense growth, and of different directions and actors showed a marked increase also thanks to the contribution of the foreigners residing in Italy" (Casacchia, Giorgi et al., 2010a, p. 1). The main metropolitan areas remain primary destinations for migrants, assuming the role of "gateways cities" (Price, Benton-Short, 2008), even though the internal mobility between the downtowns and the peripheral crown of municipalities within the larger metropolitan area shows a tendency to the decentralization of both the Italian and the foreign population (Casacchia, Giorgi et al., 2010b). At both the regional and the provincial level the tendency seems to be related also, even though with smaller numbers, to the dispersal of the foreign population from the bigger cities to the smaller towns (Istat, 2010). To summarize this tendency, the researchers of the Ismu foundation, speaking of the situation in Lombardia in a 2010 issue of their newsletter, stated: "Immigrants prefer small provinces. From the beginning of the decade to July 1st, 2009, the number of foreigners grew mainly in the "small" provinces or in the extreme North of the region : Lodi ( $+332 \%)$, Pavia ( $+314 \%)$, Mantova $(+287 \%)$, Sondrio ( $272 \%)$ and Cremona (265\%) (Ismu newsletter n. 23, November 10, $2010<$ <ww.ismu.org>). Surely this phenomenon was characterizing the Italian context also before the start of the economic crisis, and can also be read as a general tendency to establish "roots" in the destination country (Ismu, 2009). Some forms of residential relocation towards a "periphery" (not always to be meant as a physical periphery, but also as a social and economic one : poorer areas, marginal territories characterized by lower real estate prices, "interstitial" spaces within the urban system, etc.), though, can be interpreted in our opinion as responses to the economic and social "downward shift" (Perocco, Cillo, 2011, p. 14) linked to the decrease in the family income caused by unemployment or by lower salaries.

The tendency to a (at least partial) redistribution of the immigrant population at the national scale can be observed by analyzing the growth of the percentage of foreign residents in the Southern regions, traditionally characterized by lower numbers. At the national scale, in fact, the higher increases in the percentage of the foreign population took place in the year 2010 in the areas that are characterized by low percentages, such as in the Southern regions of Puglia ( $+14,2 \%)$, Basilicata and Sardinia $(+12,7 \%)$, and Calabria $(+12,1 \%)$. The growth is inferior to the 2008 one, but still higher than the ones registered in the traditionally most attractive regions of the North, such as Lombardy $(+8,6 \%)$ and Emilia-Romagna ( $+9,5 \%)$.

As for the job market, the greatest possibilities for employment do remain in the Northern and Central regions. The projections for the year 2011 see a higher impact in the Northern regions (Emilia-Romagna and Piemonte will have a $19 \%$ of foreign workers among the esteemed total number of hirings - respectively of 12,470 and 17,590), than in the Southern regions (Puglia, Sicilia and Sardegna are all below the $9 \%$, with totals of 3,550, 4,070, and 2,010) (Fondazione Moressa, 2011, p. 17). Some other data: Lombardia will have 22,740 new hirings (the highest number in Italy), with a percentage of foreign workers of $18,3 \%$; Veneto 13,480 with a $16,8 \%$; Lazio 13,480 with $18,3 \%$ as well $)^{14}$.

31 Geographical reasons of proximity are still active in the choice of the area of arrival : the Southern regions still are a privileged area of arrival (Istat, 2010, p.11), with a generalized tendency to move towards the Northern regions at a second stage of the migratory project, because of the perspective of better employment opportunities. De 
Filippo and Morlicchio spoke of the "dual role" of a Southern region, Campania, which is now both an "area of transition and an area of definitive settlement" (2010). The SouthNorth movement is still relevant today also for the Italian population: "The mobility of foreigners in Italy highly contributes to the increased internal migrations, especially as far as certain trajectories are concerned. The most relevant contribution of the foreign component is in the flows of people that go from the South of Italy towards the CenterNorth of the country, or in the flows that leave the metropolitan areas towards the municipalities in the surrounding territorial 'crown'" (Casacchia, Cassata et al. 2010, p. 64) 15 .

Possible signs of an increased mobility are related to the economic crisis. What Perocco and Cillo (2011, p. 14) labeled "circular mobility" (the search for new destinations both in Italy and in other European countries) is one of the most likely scenarios characterizing the responses to the current economic crisis.

\section{Some (temporary) conclusions and policy recommendations}

33 The impacts of the economic crisis on the immigration processes, as clearly demonstrated by Awad (2009) at the international scale, are always variegated, with striking differences from place to place, and depending on various factors, among which one can mention the economic sector that is taken into consideration, the migrants' nationality, the relationships between the country of origin and the country of destination. One of the few certainties in this continuously evolving situation is the fact that the territorial dimension already is one of the most promising dimensions for researches on immigration (Chiodini, Milano, 2010).

Integration of the immigrant communities, even more so during times of recession, appears as one of the central issues at stake, for several reasons that affect the economic, the social and the cultural dimension (Garson, 2009). Within the general goal of facilitating the integration of foreign citizens through the consolidation of the different forms of economic, social, political and cultural citizenship, the access to the housing market appears to be a key component for the process of stabilization of the migrants (Rolnik, 2009). This necessity to face the housing problem for the immigrants can be interpreted as an answer to the larger concept of the "right to the city" as defined by Lefebvre (1968) and recently, after forty years from its appearance, re-activated by Harvey (2008).

Among the six possible scenarios presented by Düvell, all of which include events and processes that are actually taking place or are very likely to happen in a near future, the one that at the moment better describes the Italian situation indicates that the "price" of the current economic crisis is heavily being paid by migrants : "the crisis is felt harder by migrant workers and the recipients of their remittances, and by ethnic minorities; the economic crisis will not generate a migration crisis but rather turn out to be an individual crisis for migrants and their families at home" $(2009$, p. 5). The current situation in Italy unfortunately shows a strict relationship between a progressive deterioration of the working conditions of foreign immigrants and a temporary deceleration of the integration processes: "the ties that linked immigrant labour in the least qualified and paid, and most precarious and dangerous, jobs are becoming stronger and stronger ; in 
times of economic stability these ties seemed to loosen; with the economic crisis, on the contrary, they prime new mechanisms of occupational stratification" (Mason, 2011, p. 1). Immigrants tend to perpetrate the role of "weak ring of the chain" in the productive system. If they were already largely disadvantaged in the Italian productive system, also due to the role that immigrant workforce occupies in it, the harshening of the global economic context did not fill the gap between the Italian workers and the immigrant ones; but the situation of both generally worsened (Bonifazi, Marini, 2011, p.5). As Perocco and Cillo (2011) efficaciously state, immigrants are "last in, first out". This seems to be particularly true for the Italian situation, where immigration is a recent phenomenon and the economic crisis is striking at its deepest impact: "[immigrant workers] were the first ones to be called to pay the bill left by the recession" (Perocco, Cillo, 2011, p. 13).

The immigrants' exposure to the consequences of the crisis is also due to the lack of social and family networks of assistance (which Paul White, 2002, considers as one of the peculiar characteristics of the immigration context in Southern Europe): "The greater fragility of the foreign population in the case of absence of working opportunities, if compared to the autochthonous population, is confirmed ; the latter, in fact, can count, in case of loss of job, on a larger help from family and social networks that allow, at least on the short run, a more elevated passage towards inactivity" (Bonifazi, Marini, 2011, p. 4 ; see also Fullin, 2011, and Reyneri, Fullin, 2011).

Thus, the necessity to organize assistance to immigrants who lost their jobs and to loosen the bureaucratic problems for this category (Cidis, 2010). Most of the reports on the complex relations between migration and the economic crisis emphasize this necessity for urgent interventions by the different level of governments, from the European Union to the national government, from the regional administrative frame to the provincial and the municipal one : "It is necessary to introduce a policy on immigration that is able to take into consideration these needs, privileging, where possible, the hiring of those immigrants that are already present in our territory, who remained without a job because of the economic crisis" (Fondazione Moressa, 2011). A similar perspective is offered in the conclusions of the report by the Cnel: "The identified measures [...] are an integrated plan to contrast illegal working, a reorganization - that cannot be postponed further - of both the private and public networks of services and, finally, active policies aimed at the full employment. The latter have to be integrated with an organic system of orientation and professional training, favoring the encounter between the offer and the demand for work, starting from the countries of origin of the migrants, and developing what is already stated in our legislation, in order to efficiently plan the immigration flows and to facilitate a qualified entrance in the job market" (2010, p. 8).

In spite of the fact that the current economic crisis has specific characteristics and cannot be fully assimilated to previous crises, it must be remembered that it is still possible to learn from the past (Dobson, Latham, Salt 2009), in order to avoid as much as possible the insurgence of xenophobic attitudes and discriminatory choices. The way in which Italy will be able to manage the immigration that is deeply affecting its socio-economic profile is a crucial step in the path towards a successful "post-ethnic Europe" (as defined by Martiniello 2005). 


\section{BIBLIOGRAPHY}

AGUSTONI A. (2009), “Abitare e insediarsi”, Quindicesimo Rapporto sulle migrazioni 2009, Milano, Fondazione Ismu, pp. 141-154.

AGUSTONI A. (2011), "Il caso italiano. Aree critiche, politiche e iniziative a livello nazionale e regionale", in AGUSTONI A., ALIETTI A. (eds.), Migrazioni, politiche urbane e abitative : dalla dimensione europea alla dimensione locale. Rapporto 2010, Milan, Franco Angeli, pp. 81-102.

ALBISINNI M., PINTALDI F. (2011), “L'impatto della crisi sul mercato del lavoro", in CARITASMIGRANTES, Immigrazione. Dossier Statistico 2011. XXI Rapporto, Rome, Idos, pp. 239-247.

ALLASINO E., EVE M. (2010), “Le radici sociali dell'immigrazione”, in PERULLI P., PICHIERRI A. (eds.) La crisi italiana nel mondo globale. Economia e società del Nord, Turin, Einaudi, pp. 239-273.

AMBROSINI M. (2001), La fatica di integrarsi. Immigrati e lavoro in Italia, Bologna, il Mulino.

AMBROSINI M. (2005), Sociologia delle migrazioni, Bologna, Il Mulino.

AMBROSINI M. (2010), "Il mercato del lavoro immigrato", in REGINI M. (ed.), La sociologia economica contemporanea, Bologna, il Mulino, pp. 204-230.

AMBROSINI M., BERTI F. (2003), Immigrazione e lavoro, Milan, Franco Angeli.

AWAD I. (2009), The global economic crisis and migrant workers : Impact and response, Geneva, International Labor Office (www.ilo.org/public/libdoc/ilo/2009/ 109B09_130_engl.pdf).

BANCA D'ITALIA (2009), Rapporto sulle economie regionali, Rome, Bankitalia.

BONIFAZI C., MARINI C. (2011), "Il lavoro degli stranieri in Italia in tempo di crisi”, L'economia dell'immigrazione. Studi e riflessioni sulla dimensione economica degli stranieri in Italia, 0, 1 (December), pp. 1-5.

BONIFAZI C., RINESI F. (2010), "I nuovi contesti del lavoro : l'immigrazione straniera", in LIVI BACCI M. (ed.), Demografia e capitale umano, Bologna, Il Mulino, pp. 139-174.

BORJAS G.J. (1999), “The Top ten Symptoms of Immigration”, Washington DC, Backgrounder.

CARITAS MIGRANTES (2011), Dossier Statistico Immigrazione. XXI Rapporto, Rome, IDOS.

CASACCHIA O., CASSATA L., GIORGI P., REYNAUD C., STROZZA S. (2010), "La mobilità interna in Italia : le principali caratteristiche dei cambiamenti di residenza", Rivista Italiana di Economia Demografia e Statistica, 64, 1-2 (Jan-June), pp. 63-70.

CASACCHIA O., GIORGI P., REYNAUD C., STROZZA S., TUCCI E. (2010a), Italians and Foreigners' Internal Mobility in Italy : an Application of Gravitational Models, paper presented at the 45th Scientific Meeting of the Italian Society of Statistics, Padua, June 16-18, (homes.stat.unipd.it).

CASACCHIA O., GIORGI P., REYNAUD C., STROZZA S., TUCCI E. (2010b), Dinamiche migratorie interne ed evoluzione delle aree metropolitane : il ruolo degli stranieri, paper presented at the 47th Scientific Meeting of the Italian Society of Economics, Demography and Statistics, Milan, May 27-29.

CASTLES S. (2009), Migration and the global financial crisis : a virtual symposium, February 2009, www.age-of-migration.com/na/financialcrisis/index.html. 
CESAREO V. (2011), “Casa, immigrazione e territorio : un'introduzione”, in AGUSTONI A., ALIETTI A. (eds.), Migrazioni, politiche urbane e abitative : dalla dimensione europea alla dimensione locale. Rapporto 2010, Milan, Franco Angeli, pp. 17-24.

CHIODINI L., MILANO R. (eds.) (2010), I volti dell'integrazione. Il ruolo delle comunità locali, dei cittadini e dei mass media nei processi di inclusione dei rifugiati in Italia, Roma, Cittalia - Fondazione Anci Ricerche, www.serviziocentrale.it/ file/server/file/I \%20volti \%20della \%20Integrazione \%20- \% 20Cittalia \% 202010(1).pdf.

CIDIS, Immigrati : la crisi colpisce due volte, www.cidisonlus.org/focus10c.html.

CNEL - Consiglio Nazionale dell'Economia e del Lavoro (2010), Indici di integrazione degli immigrati in Italia. Il potenziale di integrazione nei territori italiani. Analisi dell'occupazione e della criminalità per collettività. VII Rapporto, Rome, CNEL (www.cnel.it).

CNEL - Consiglio Nazionale dell'Economia e del Lavoro (2011), Rapporto sul mercato del lavoro 2010-2011, Rome, CNEL (www.cnel.it).

CONTI C., GUARNERI A., LICARI F., TUCCI E. (2010), "La mobilità interna degli stranieri in Italia : uno studio attraverso il record linkage tra archivi", Rivista Italiana di Economia Demografia e Statistica, 64, 1-2 (Jan.-June), pp. 79-86.

DE FILIPPO E., MORLICCHIO E. (2010), Economic recession and the internal migration of immigrants in Italy, paper presented at the International Conference "Rethinking Migration in Times of Economic Crisis in Europe”, Bremen, Dec 9-10, 2010 (www.migremus.uni-bremen.de).

DOBSON J., LATHAM A., SALT J. (2009), On the move? Labour migration in times of recession. What can we learn from the past, Policy Network Paper, 6 July 2009, www.policy-network.net/publications/ publications.aspx?id=2688.

DÜVELL F. (2009), The Crisis and its Possible Impact on Global Migration, Oxford, Centre on Migration, Policy and Society (COMPAS), www.age-of-migration.com/uk/financialcrisis/updates/1f.pdf.

FAVARO G., MUSCARÀ C. (eds.) (2009), Il Nord Est dopo il Nord Est, Noventa Padovana (PD), Nexta books.

FONDAZIONE LEONE MORESSA (2010), Indice di attrattività occupazionale degli stranieri. Un'analisi regionale, Mestre (VE), www.fondazioneleonemoressa.org.

FONDAZIONE LEONE MORESSA (2011), "La domanda di manodopera straniera in Italia. Per effetto della crisi, cala il fabbisogno di lavoratori immigrati”, L'economia dell'immigrazione. Studi e riflessioni sulla dimensione economica degli stranieri in Italia, 0, 1 (December), p. 16-19.

FONDAZIONE LEONE MORESSA (forthcoming January 2012), Rapporto annuale sull'economia dell'immigrazione. Edizione 2011. Gli stranieri : un valore economico per la società. Dati e considerazioni su una realtà in continua evoluzione, Bologna, il Mulino.

FRONTEX - European Agency for the management of Operational Cooperation at the External Borders of the EU Member States (2009), The impact of the global economic crisis on illegal migration to the $E U$, www.frontex.europe.eu.

FULLIN G. (2011), “Tra disoccupazione e declassamento occupazionale. La condizione degli stranieri nel mercato del lavoro italiano”, Mondi Migranti, 1, pp. 195-228.

FULLIN G., REYNERI E. (2011), “Low Unemployment and Bad Jobs for Immigrants in Italy”, International Migration, 49, pp. 118-147.

GARSON J.-P. (2009), "Malgré la crise, les pays doivent continuer à intégrer les immigrés, car ils font partie de leur économie", Le Monde, February 25, www.lemonde.fr. 
HARVEY D. (2008), “The Right to the City”, New Left Review, September-October, p. 32.

HATTON T., WILLIAMSON J. G. (2009), “Global economic slumps and migration”, Vox - Researchbased policy analysis and commentary from leading economists, www.voxeu.org.

IOM (2009), The impact of the global financial crisis on migration, Geneva, IOM, www.osce.org/ documents/eea/2009 /01/35935_en.pdf.

ISMU (2009), Fifteenth Report on Migrations, Milan, Franco Angeli.

ISMU (2010), XVI Rapporto sulle migrazioni, Milan, Franco Angeli.

ISMU (2011), XVII Rapporto sulle migrazioni, Milan, Franco Angeli.

ISMU-CENSIS-IRPS (2010), Immigrazione e lavoro. Percorsi lavorativi, Centri per l'impiego, politiche attive, Milan, Franco Angeli.

ISTAT (2010), La popolazione straniera residente in Italia al $1^{\circ}$ gennaio 2010, Roma, Istat, www.istat.it.

LEFEBVRE H. (1968), Le droit à la ville, Paris, Anthropos.

CASTLES S., MILLER M. (2010), Migration and the Global Economic Crisis: One Year On, www.age-ofmigration.com/na/financialcrisis/updates/migration_crisis_april2010.pdf.

MASON R. (2011), "Editorial”, L'economia dell'immigrazione. Studi e riflessioni sulla dimensione economica degli stranieri in Italia, 0, 1 (December), p. 1.

MARTINIELLO M. (2005), “Towards a Post-Ethnic Europe”, in BOSSWICK W., HUSBAND C. (eds.), Comparative European Research in Migration, Diversity and Identities, Bilbao, University of Deusto, pp. 13-24.

NEGRI N. (2006), "La vulnerabilità sociale. I fragili orizzonti delle vite contemporanee”, Animazione sociale, August-September, pp. 14-19.

OECD - Organisation for Economic Cooperation and Development (2009a), International Migration and the Financial Crisis: Understanding the Links and Shaping Policy Responses, Paris, OECD.

OECD - Organisation for Economic Cooperation and Development (2009b), International Migration and the Economic Crisis, www.oecd.org.

PAPADEMETRIOU D. G., SUMPTION M., SOMERVILLE W. (2009), Migration and the economic downturn : what to expect in the European Union, Washington DC, Migration Policy Institute, www.age-of-migration.com/uk/financialcrisis/updates/1e.pdf.

PASCA E. (2010), La crisi economica non ferma gli immigrati, www.stranieriinitalia.it.

PEROCCO F., CILLO R. (2011), “L'impatto della crisi sulle condizioni lavorative degli immigrati”, L'economia dell'immigrazione. Studi e riflessioni sulla dimensione economica degli stranieri in Italia, 0, 1 (December), pp. 13-15.

PERULLI P., PICHIERRI A. (eds.) (2010), La crisi italiana nel mondo globale. Economia e società del Nord, Turin, Einaudi.

PIRAS R., MELIS S. (2007), "Evoluzione e tendenze delle migrazioni interne”, Economia Italiana, 2 , pp. 437-461.

PRICE M., BENTON-SHORT L. (eds.) (2008), Migrants to the Metropolis. The Rise of Immigrant Gateway Cities, Syracuse, Syracuse University Press.

PUGLIESE E. (2006), L'Italia tra migrazioni internazionali e migrazioni interne, Bologna, il Mulino, (2nd ed.). 
REYNERI E. (2010), “L'impatto della crisi sull'inserimento degli immigrati nel mercato del lavoro dell'Italia e degli altri paesi dell'Europa meridionale”, Prisma. Economia, società e lavoro, 2, pp. 17-33.

REYNERI E., FULLIN G. (2011), "Labour market penalties of new immigrants in new and old receiving West European countries", International Migration, 49, pp. 31-57.

ROLNIK R. (2009), Report of the Special Rapporteur on adequate housing as a component of the right to an adequate standard of living, and on the right to non-discrimination in this context, Human Rights Council, February, daccess-dds-ny.un.org/doc/UNDOC/GEN/N09/446/64/PDF/N0944664.pdf? OpenElement.

RUIZ I., VARGAS SILVA C. (2009), “Another consequence of the economic crisis : a decrease in migrants' remittances”, Applied Financial Economics, 20, 1, pp. 171-182.

UN-INSTRAW (2009), The Financial Crisis and Migration Myths, 2009, www.un-instraw.org.

WHITE P. (2002), "Migration and Mediterranean Urban Societies : Policy Contexts and Concerns", in FONSECA M. L., MALHEIROS J., RIBAS-MATEOS N., WHITE P., ESTEVES A. (eds.), Immigration and Place in Mediterranean Metropolises, Lisbon, Luso-American Development Foundation, pp. 13-29.

WORLD BANK, "People Move, A blog about migration, remittances, and development" Washington, D.C.

ZANFRINI L. (2010), "Il lavoro", in Sedicesimo Rapporto sulle migrazioni 2010, Milan, Franco Angeli, pp. 98-113.

\section{NOTES}

1. The present article is the result of a research carried on in collaboration by the two authors within the 2008 Prin - Scientific Research Project of National Relevance entitled "Migrations and cultural interaction processes. Patterns of integrations and spatial organization in Italian local cases" (scientific coordinator Carlo Brusa) and funded by the Italian Ministery of Education. In particular, Carlo Brusa is the author of paragraphs 2, while Davide Papotti of paragraphs 1, 3, 4 and 5. A preliminary version of this paper was presented in Haifa at the International Geographical Union (Igu) "Globility" Commission (Chair: Armando Montanari) 2010 meeting "Human Mobility in the Time of a Global Economic Crisis". The authors wish to thank the organizers and the participants for the useful feedbacks provided during the conference. The authors also thank the three anonymous referees who provided useful critiques and suggestions for the improvement of the text.

2. One of the "top ten symptoms of immigration" according to George Borjas (1999). For a historical overview of the relation between the Italian labor market and immigration, see Ambrosini, 2001 and Ambrosini, Berti, 2003.

3. All the quotations from Italian essays, if not otherwise noted, are by the authors.

4. www.istat.it. For a recent comment on the last available data on immigration in Italy, see Ismu, 2011, and Caritas Migrantes, 2011.

5. http://www.ismu.org. Other researches show greater numbers; for instance the research conducted jointly by Censis, Iprs and Ismu speak of 566,000 irregular immigrants (Rapporto sui percorsi lavorativi - 2010) (http://www.censis.it). For a general research on the impact of the economic crisis on illegal migration in Europe see Frontex, 2009. 
6. Following the most common trend in international atlases published in the AngloAmerican context, we decided to use the original Italian name of the regions, instead of the translated ones (i.e Toscana instead of Tuscany, Lombardia instead of Lombardy etc.).

7. For further information see the website www.fondazioneleonemoressa.org. The data were updated to the first trimester of 2010, and derived from the Istat databases.

8. Data source : Istat, elaborated in Ismu, 2011. On this topic, with similar conclusions, see also Fullin, Reyneri, 2011. For a general overview of the working mobility of foreign immigrant within the Italian labour system, see Ismu-Censis-Irps, 2010. For an example of comparative analysis regarding Southern European countries, see Reyneri, 2010 ; Bonifazi, Rinesi, 2010.

9. On this topic there will also be an extensive documentation on the forthcoming report by the Fondazione Moressa (2012), as documented in the preview available online: http:// www.fondazioneleonemoressa.org

10. See the updated data on the periodical reports by Cescat - Centro Studi Assoedilizia, available on www.assoedilizia.com.

11. See for instance the note titled Istat, bilancio demografico 2009 in the Ismu Newsletter n. 23, released on November 10, 2010 ; http://www.ismu.org

12. For a similar research on the territorial power of attraction of the Italian Regions for the immigrants, see the detailed analysis of the Italian socio-economic structure in Cnel, 2010.

13. Ismu Newsletter 23, 2010 ; http://www.ismu.org.

14. The estimated numbers were calculated by the scholars working at the Fondazione Moressa taking into consideration data from Excelsior, Unioncamere, and the Ministry of Interior (Fondazione Moressa, 2011, p. 17).

15. On the relations between international mobility and national mobility in Italy, see Pugliese, 2006. On Italian internal mobility see also Piras, Melis, 2007.

\section{ABSTRACTS}

The article offers a synthetic overview of the main effects that the international economic crisis has had on immigrants in Italy. After a brief introductory explanation of the main characteristics of the Italian context of immigration, the authors concentrate on two main problems: the immigrants' access to the labour market and to the housing system. The so-called "social vulnerability" of migrants was increased by the tensions related to the economic crisis. The growing problems that immigrants have been facing in the last three years are linked to the territorial distribution and to the mobility of the migrant communities on the national territory. The tendency to a progressive redistribution of the migratory destinations and to an increased mobility within and outside the Italian national borders are among the consequences of the socio-economic difficulties suffered by migrants. Finally, a few conclusive remarks suggest some policy recommendations.

L'article offre une vue d'ensemble synthétique des effets principaux que la crise économique internationale a eus sur les immigrés en Italie. Après une brève explication des caractéristiques principales du contexte italien de l'immigration, les auteurs se concentrent sur deux problèmes principaux: l'accès des immigrés au marché du travail et au système de logement. La "vulnérabilité sociale" des migrants a été augmentée par les tensions liées à la crise économique. 
Les problèmes croissants que les immigrés ont rencontrés ces trois dernières années sont alors liés à la distribution territoriale et à la mobilité des communautés migratrices sur le territoire national. La tendance à une redistribution progressive des destinations migratrices et à une mobilité accrue dans et en dehors des frontières nationales italiennes sont parmi les conséquences des difficultés socio-économiques souffertes par les migrants. En conclusion, quelques remarques suggèrent une série de recommandations de politique.

INDEX

Mots-clés: Italie, immigration, crise économique, mobilité

Keywords: Italy, immigration, economic crisis, mobility

\section{AUTHORS}

\section{CARLO BRUSA}

Università del Piemonte Orientale “Amedeo Avogadro", Dipartimento di Studi Umanistici, Via Manzoni 8, 13100, Vercelli, Italy, carlo.brusa@lett.unipmn.it

\section{DAVIDE PAPOTTI}

Università di Parma, Dipartimento di Scienze della Formazione e del Territorio, Borgo Carissimi, 10/12, 43121, Parma, Italy, davide.papotti@unipr.it 